\title{
METHODS OF DIRECTING ECONOMICS TO SCIENTIFIC RESEARCH ACTIVITIES
}

\section{Gulsanam Nazarova}

Independent Researcher Fergana Polytechnic Institute, Uzbekistan

\section{ABSTRACT}

The article analyzes the current pedagogical conditions, factors, stages, components, methods of directing research activities in future economists. The article also examines the pedagogical-hierarchical system of forms of manifestation of research skills in future economists.

KEYWORDS :- Thinking, analytical thinking, scientific research, future economist, education, higher education, teaching and learning process, method, debates, methodological requirements, effectiveness of teaching and learning, debate, independent thinking.

\section{INTRODUCTION}

Paragraph 4.4 of the Decree of the President of the Republic of Uzbekistan dated February 7, 2017 No PF-4947 "On the Strategy for further development of the Republic of Uzbekistan" entitled "Development of education and science" to further improve the system of continuing education Much attention is paid to the development of preschool education, radical improvement of the quality of general secondary education, deepening of science teaching, improving the quality and efficiency of higher education, stimulating research and innovation [1].

Taking this into account, it is an important task for teachers to bring the specialists trained in the higher education system to the level of world standards, to pay special attention to the training of scientific and pedagogical staff, to direct students to research work.

Modern education in economics higher education is problem-based teaching, research, and problem-solving. Such a learning process is widely used in the practice of educational institutions in accordance with the goals of educating the creative activity of the individual, along with problem-based learning, illustrative explanation, information and programmed educational technology.

\section{Materials AND Methods}

"Knowledge Economy", "Innovative Economy" and Economics

It is necessary to form creative thinking in students in the process of passing the relevant disciplines. This will involve future economists in problematic situations, discuss critical situations, find problems in them independently and create and defend their own projects, cases to solve them, serve to broaden the minds of students.

\section{Results AND DISCUSSION}

In our opinion, the role of student independence in the process of problem-based learning of economics is much more effective when 
CURRENT RESEARCH JOURNAL OF PEDAGOGICS 2(6): 90-95, June 2021

DOI: https://doi.org/10.37547/pedagogy-crjp-02-06-18

ISSN 2767-3278

(C)2021 Master Journals

\section{Crossref dof 81 Google}

Accepted 18 th June, 2021 \& Published 23 ${ }^{\text {th }}$ June, 2021

compared to reproductive learning methods. The purpose of problem-based learning is to find answers to educational problems, problems and questions in the process of working with students, to acquire new knowledge by solving them, to arouse the interest of teachers in creating and solving problem situations in students' learning activities. Jumaladan:

1. Analyzing and thinking about the problems that arise in the economy is one of the important requirements for the development of independent intellectual activity of students. Such thinking leads the student to take seriously the meaning of the sentence, to form his thinking, realizing that he did not understand it.

2. In order to make economic thinking effective and expedient in the process of teaching in higher education institutions, it is necessary to make it a part of the educational process, the basis of educational work. With the help of problem-based education, future economists develop a research approach to solving educational problems and specialization issues, the development of economic thinking, the formation of skills for independent study.

3. Economic education helps students to effectively master their knowledge systems and intellectual and practical activities, to form their thinking, to use their new knowledge effectively in future situations, to solve educational problems, to teach independent research, to gain and develop creative experience, analysis reveals opportunities to identify problem-based learning.-

The great German pedagogue A. Disterverg states that "a bad teacher tells the truth, and a good teacher teaches to find it" [2].

L.A. Avetisova in her article "Students 'research activities - a model of pedagogical technology" shows the stages of implementation of students' research work [3].

As a result of research work and articles in the field of orientation of future economists to research work, it was revealed that students and masters who want to engage in research work in higher education have significant problems. These problems are:

1. Inability to choose the right research topic.

2. Lack of knowledge of scientific research methods and their use.

3. Inability to independently prepare a statement of research work.

4. Challenges in working with literary sources.

5. Lack of ability to make a presentation of the research work done.

Orientation of future economists to research can be done in two ways [4]:

- The first, directly in the classroom: the organization of problem-solving lessons in seminars, practical classes, setting and encouraging problem-solving tasks, the creation of educational projects (lesson plans, technological maps, electronic manuals) in the specialty or subject of students ;

- The second is a logical continuation of the lesson, the implementation of extracurricular research activities: independent work, abstracts, term papers, research, research work, participation in Olympiads and exhibitions and scientific articles at conferences.

The beginning of research work of future economists is, firstly, the ability to independently perform the tasks given by the teacher in theoretical and practical classes, using the scientific literature in libraries and present it in the form of independent work, abstracts, coursework, and secondly, individual research work (graduate work participation in various 
CURRENT RESEARCH JOURNAL OF PEDAGOGICS 2(6): 90-95, June 2021

DOI: https://doi.org/10.37547/pedagogy-crjp-02-06-18

ISSN 2767-3278

(C)2021 Master Journals

\section{Crossref dof 81 Google}

Accepted 18 th June, 2021 \& Published 23 ${ }^{\text {th }}$ June, 2021

projects).

Higher education professors and teachers should train future economists to solve existing problems in order to start research work as follows:

1. To teach students to choose the right research topic. This is a very complex process, and the progress and positive outcome of the research work will depend on the choice of topic. The topic reflects the specifics of the research work and is selected in collaboration with the student and his supervisor. When choosing a research topic:

The opportunity to discuss in the pages of scientific research, to express their personal views, to conduct research;

- the lack of a wide range of research topics, taking into account the adequacy of the scientific knowledge and skills of the researcher;

The availability of materials for research, in some cases, the topic is interesting, but there are not enough materials to do it.

2. Teaching research methods and their use. Conducting research is a way to regulate the evidence, to study the laws. Research methods are a way to achieve goals in scientific work. The science that deals with the study of methods is called 'Methodology'.

We know that every scientific research work is carried out using certain scientific research methods. It is necessary to teach how to use research methods such as analysis and synthesis, comparison, classification, modeling, observation, experiment and interview in the process of conducting research work. Without a good method, even the right method will not give good results. If methodology is a method of applying a method, methodology is the teaching of methods.

According to V.S.Lednev, the researcher must have a system of scientific knowledge in order to use research methods, and it will be as shown in Figure 1 [5].

Philosophical methods are based on dialectical and metaphysical methods, in addition to philosophical methods: intuitive, analytical, dogmatic, sophistic, and others.

General scientific methods allow the study of methods of acquiring any everyday human knowledge, along with the analysis of the thinking process. This includes the following theoretical level methods:

The method of analysis involves the study of individual parts of a whole object, in parts, for a more detailed study of its properties.

The method of synthesis involves combining the studied parts of the subject and generalizing the results of the analysis. If the analysis method is performed at the beginning of the study, the synthesis method completes it.

The method of abstraction is the study of abstraction into reality as a result of thinking [6].

The method of generalization includes methods of identification, comparison of facts in the research, preliminary conclusions, visualization of the dynamics of the event, the formalization of the results of generalization using conditional symbols, general conclusions.

The induction method is a method of drawing general conclusions based on known facts.

The method of deduction is to draw a special conclusion based on general opinion. It would also be useful for us to teach students the use of observation, description, experiment, comparison, formalization, and other methods [7].

3. To teach independent preparation of the regulations of scientific research work. Students are taught to choose the direction of the problem on the chosen topic, to show the relevance of the 
CURRENT RESEARCH JOURNAL OF PEDAGOGICS 2(6): 90-95, June 2021

DOI: https://doi.org/10.37547/pedagogy-crjp-02-06-18

ISSN 2767-3278

(C)2021 Master Journals

\section{Crossref dof 81 Google}

Accepted 18 th June, 2021 \& Published 23 ${ }^{\text {th }}$ June, 2021

topic on the basis of adopted laws, decisions, to choose the object, to define the subject, to explain that the success of any research depends on clearly defining the goal. formation, scientific novelty of the subject, the preparation of a charter showing the practical significance.

4. Teach students to work with literary sources. An analysis of the research literature allows the student to become familiar with the problem situation by showing that he or she is familiar with several sources in the field of research. It will be necessary to convey to the student that the validity of the hypothesis raised in the research work must be backed up by literary data and logical reasoning.

Future economists should be directed to search the literature on research work, to study the nature of the problem from the literature found, to systematically describe the problem-solving method, and to independently compile a list of references. Today, students use Internet resources, electronic publications to conduct research. In this case, the source of information is very large, from which it is important to choose exactly what is needed, to state in an orderly manner, to draw independent conclusions, to make decisions. Sometimes there are deviations from the topic.

5. Develop the ability to make a presentation of the research work done. The results of the observations show that the research paper, thesis, report, research plan, text for oral presentation, presentation, problem-based essay, computer presentation, video, audio, depending on the purpose and content of the research work presented by the student. materials, various training projects, etc. In presenting research papers in this form, students are asked to present the work done on time using computer slides, use graphs, diagrams to present the results of the work, clearly express their opinions, conclusions, clear and fluent speech, attention to tone, logical, thoughtful answers to questions. will need to be trained to give.

Because the process of conducting research work is a complex process, not all students can enter the process at once. Therefore, we can include the following in the main task of the teacher in directing students to research activities:

1. To increase the interest of future economists in scientific work, to encourage them to solve scientific research problems independently, to form research skills [8].

2. Improving, strengthening and developing the study of independent creative thinking, theoretical and practical knowledge.

3. Achieving the formation of research skills of future higher education specialists [9].

4. Solve current problems using the creative and scientific potential of talented and gifted students and show it as an example to all students, etc.

At different stages of scientific research work, the role of the scientific leader, professor-teacher will be different. For example [10]:

At the diagnostic stage, the teacher has a tendency to conduct research, gathers knowledgeable, able to perform tasks independently, determines their area of interest, what type of work they can do, encourages research. At the same time, the teacher should be active in bringing the relationship between the student and the teacher closer.

At the stage of putting the research topic, the teacher focuses on working on several types of topics, introduces the literature, Internet addresses. In collaboration with the supervisor and the researcher, the topic is identified, its relevance, purpose, object, subject, tasks, scientific novelty are determined. In this, the 
CURRENT RESEARCH JOURNAL OF PEDAGOGICS 2(6): 90-95, June 2021

DOI: https://doi.org/10.37547/pedagogy-crjp-02-06-18

ISSN 2767-3278

(C)2021 Master Journals

\section{Crossref dol 81 Google}

Accepted $18^{\text {th }}$ June, 2021 \& Published 23 $3^{\text {th }}$ June, 2021

teacher plays the role of a consultant, the role of the teacher is superior, not active, more researchers need to be achieved.

During the research phase, the teacher is the consultant and the research student should be given a high degree of independence. As a researcher, the student is required to work independently on the content of the topic, the teacher asks a variety of guiding questions that help to solve the problem. It is at this stage that the student uses research methods and has a personal opinion on his / her research work, makes independent decisions, learns to give conclusions and suggestions, completes the work.

Scientific activity carried out in the defense phase is analyzed. At this time, the student and the supervisor, the teacher are equal partners. At the end of the defense, the activity is evaluated.

Conducting research activities with students imposes the following requirements on the teacher:

- Have a positive attitude towards the student, respect him as a person;

- Recognize the unique characteristics of the student, give him the right to choose, freedom;

- Taking into account the individual, psychological characteristics of the student, evaluating his performance, not himself.

\section{Conclusion}

In short, with the development of science and technology, it is necessary to update, deepen and strengthen the acquired knowledge, to direct students to scientific research, to shape their scientific activity, to allow the next generation to engage in scientific activity, to solve problems in a timely manner. identification, attention should be paid to their elimination. Involvement of future economists in research is educational, it helps the student to believe in their own strength and power to achieve the goal, the desire to know, the formation of a scientific worldview, independence of thought, satisfaction with their work, aesthetic needs and the inner beauty of science.

\section{REFERENCES}

1. Республикасини янада ривожлантириш бўйича Харакатлар стратегияси тўғрисида»ги ПФ-4947-сон фармони. // Ўзбекистон Республикаси қонун хужжатлари тўплами, 2017 й., 6-сон, 70модда.

2. Каюмова Н.А. Педагогик ва ахборот технологиялари информалтика интеграциясида тайёрлашнинг методик тизимини ишлаб чиқиш. // «Замонавий таъ ллим» журнали, 2018, № 4. -34-40-б.

3. Қаюмова Н.А. Педагогик ва ахборот технологиялари интеграциясида информал3. тика ўқитувчисини тайёрлашнинг методик тизими. / Монография. - Т.: «Фан ва техноллогия», 2018. -148-б.

4. Потапова Е.Н. Формирование исследовательской компетенции на уроках инфор 4 . матики. // http://tmo.ito.edu.ru/2014/section/229/9 4666/index.html

5. Аветисова Л.А. Научноисследовательская деятельность учащихся - модель педалгогической технологии. / // Открытый урок.рф/статьи/620136/

6. Рябова Л.Г. Исследовательская деятельность учащихся. // Открытый урок.рф/6. статьи/581619 
CURRENT RESEARCH JOURNAL OF PEDAGOGICS 2(6): 90-95, June 2021

DOI: https://doi.org/10.37547/pedagogy-crjp-02-06-18

ISSN 2767-3278

(C)2021 Master Journals

\section{Crossref dof 81 Google}

Accepted 18 th June, 2021 \& Published 23 ${ }^{\text {th }}$ June, 2021

7. Гуманитарная энциклопедия. // https://gtmarket.ru/concepts/7008 7.

8. Методы исследования, как они есть. // https://nauchniestati.ru/blog/metody-8. issledovanija/

9. Леонтович А.В. Учебноисследовательская деятельность школьника как модель 9. педагогической технологии. // Журнал «Народное образование», 1999, № 10. -С. 152-158.

10. Bakhromovich, S. I. (2020). The impact of managerial professional development on the effectiveness of Higher Education institution management. Academicia: an international multidisciplinary research journal, 10(12), 1014-1020... 